\title{
Acidic Soil Improvement and Physicochemical Characteristics Using Red-mud and Biochar
}

\section{Dong Shin - Young-Tae Jo $\cdot$ Seong-Jae Park - Jeong-Hun Park ${ }^{\dagger}$}

Department of Environment and Energy Engineering, Chonnam National University

(Received July 22, 2019; Revised September 3, 2019; Accepted September 9, 2019)

Objectives: Total waste that is generated in South Korea per land area is ranked in fourth among OECD countries. Therefore, the importance of resource circulation through waste recycling should be emphasized. Red mud, one of the industrial wastes, is a by-product of the aluminum smelting process and is generated about 300 thousand tons per year.

Methods: Red mud is high in iron content and has a red color and strong alkalinity. Rice husk, a by-product of agricultural production, can be made into biochar through pyrolysis process and it also has alkalinity. By using red mud and biochar as soil amendment, experiment was conducted. The purpose of the experiment is to improve the quality of the acidic soil and find the growth-characteristics (length, width, weight, dry weight) through pot experiment.

Results and Discussion: The acid soil with a $\mathrm{pH}$ level of 4.84 was increased to $\mathrm{pH} 7.14$ after adding the amendment. The CEC of the soil with $7.56 \mathrm{cmol}_{\mathcal{C}} / \mathrm{kg}$ was increased to $9.80 \mathrm{cmol}_{\mathcal{C}} / \mathrm{kg}$. Pot experiment showed better results of growth-characteristics in treatment than control. The analysis of heavy metals showed below standard level in both control and treatment.

Conclusion: Therefore, the pot experiment showed that red mud and biochar could be used to improve acid soil effectively.

Key words: Red Mud, Biochar, Soil Improvement, Amendment, Acidic Soil 


\section{연구논문}

\section{산성토양 개량을 위한 레드머드 및 바이오차의 적용과 이화학적 특성 연구}

\section{신 동·조영태 - 박성재 - 박정훈 ${ }^{\dagger}$}

전남대학교 환경에너지공학과

목적: 국토의 단위면적당 총 폐기물 발생량은 $\mathrm{OECD}$ 국가 중 4 번째에 속해 있다. 이에 폐기물의 재활용을 통한 자원순환의 필요성이 강조되어야 하는 실정이다. 산업 폐기물의 하나인 레드머드는 알루미늄 제련 공정의 부산물이며 한 해 약 30 여만 톤이 발생하고 있다.

방법 : 레드머드는 철 함량이 높아 붉은색을 띠며 강알칼리성을 보유하고 있다. 농업 생산 과정에서 발생하는 부산물인 왕겨는 열분해 공정을 통해 바이오차로 제조되며 약알칼리성을 보유하고 있다. 이들을 토양 개량제로써 활용하여 산성화된 토양을 개량함과 동시에 토양화학특성 $(\mathrm{pH}, \mathrm{CEC}$ 등)을 파악하고 상추 생육을 통한 생육지표(엽장, 엽폭, 생체중, 건체중)를 조사하였다.

결과 및 토의: 대조구인 산성토양의 $\mathrm{pH}$ 는 개량제(레드머드 $1 \%$, 바이오차 $2 \%$ ) 처리 시 4.84 에서 7.14 로 증가하였고, $\mathrm{CEC}$ 는 처리구 7.56 에서 $9.80 \mathrm{cmol}_{\mathrm{c}} / \mathrm{kg}$ 로 증가하여 대조구에 비해 개선되었다. 상추 생육 실험 결과 대조구에 비해 처리구에서 생육지표(엽장, 엽폭, 생체중, 건체중)의 우위를 보였다. 토양 중금속 분석결과에서 대조구 및 처리구 토양 모두 중금속 우려기준 이하로 조사되었다. 재배된 상추의 중금속 분석결과 엽채류의 기준 항목인 $\mathrm{Pb}, \mathrm{Cd}$ 의 농도는 기준치 이하로 검출되었다.

결론 : 따라서 레드머드 및 바이오차를 활용하여 산성토양을 효과적으로 개량할 수 있는 것으로 나타났다.

주제어 : 레드머드, 바이오차, 토양 개량, 개량제, 산성토양

\section{1. 서 론}

산업의 발전과 함께 인구가 증가하고 그에 따라 인류의 자원 요구량은 증가하고 있다. 오늘날의 자원 흐름은 늘어 나는 수요량에 따른 공산품의 대량생산-대량소비 시스템으 로써 종국에는 대량의 폐기물을 배출하게 된다. 이러한 흐 름은 인류에게 자원고갈, 환경오염, 에너지 부족 등의 문제 를 불러올 수 있다. 특히 우리나라는 $90 \%$ 의 광물 자원, $97 \%$ 의 에너지를 수입에 의존하고 있으며, 국토의 단위면 적당 발생되는 총 폐기물은 $\mathrm{OECD}$ 국가 중 4번째에 속해 있다. 이에 현재 국내에서 발생하는 폐기물을 재활용함과 동시에 자원순환의 필요성이 강조되어야 하는 실정이다. ${ }^{1)}$ 이에 따라 최근 폐기물 자원순환의 일환으로 폐기물을 활 용하여 토양을 개량하는 연구가 진행되고 있다. 토양 개량 에 이용되는 개량제는 크게 염기성 물질(Alkali substance) 을 포괄하고 있다. 세부적으로는 산업 부산물(Industrial byproducts)인 레드머드(RM, red mud), 비산재(Fly ash) 등 이 있으며, 농업 부산물(Agricultural byproducts)인 바이오 매스(Biomass)를 일정 온도에서 열분해(Pyrolysis)하여 탄화 고형물의 형태로 제조한 바이오차(BC, biochar)가 있다. 또 한 패각류(Shells)인 굴껍질, 홍합껍질 등의 해양 부산물을 토양 개량제로 활용하는 연구도 진행되고 있다. ${ }^{2}$

이 중 산업 부산물인 레드머드(RM, red mud)는 보크사 이트(Bauxite)로부터 알루미늄을 추출하는 과정에서 발생 하는 부산물이다. 현재 국내의 경우, 주요 발생처인 $\mathrm{K}$ 사에 서 한 해 30 여만 톤의 레드머드 슬러지가 발생하고 있으며, 대부분이 폐기되거나 토목공사의 성토재로 사용되고 있다. 그러나 알루미늄 관련 산업의 성장으로 보크사이트의 수입 량은 증가하고 그에 따라 레드머드의 발생량 또한 점차 커 지면서 매년 약 8 만 톤가량이 처리되지 않고 있으며 미처 리되는 양은 지속적으로 증가하고 있는 추세이다. 더불어 기존의 해양투기로 처리해왔던 것과 달리 국제협약에 따른 
해양투기 금지 문제로 인해 향후에는 재활용을 통한 보다 다각화된 연구 개발이 필요할 것으로 보인다. ${ }^{3 \sim 5}$

보크사이트(Bauxite) 제련 공정에서 발생한 레드머드는 다량의 $\mathrm{Fe}_{2} \mathrm{O}_{3}, \mathrm{Al}_{2} \mathrm{O}_{3}$ 화합물을 보유하고 있고, 2 3 $\mu \mathrm{m}$ 의 매우 작은 미립자로 이루어져 있다. 이 중 철 성분은 레드 머드에 붉은색을 띠게 하며 제련 과정에서 첨가되는 가성 소다 $(\mathrm{NaOH})$ 로 인해 강알칼리성 $(\mathrm{pH} 11$ 이상)을 띠게 된다. 레드머드를 이용한 토양의 개량이나 토양 내 중금속 안정 화 등의 연구들은 이러한 알칼리성 물질인 레드머드를 토 양에 적용하여 산성화된 토양을 중화시켜 $\mathrm{pH}$ 의 상승효과 를 이용한 결과이다. ${ }^{3,5,6)}$

한편, 농업 부산물인 바이오매스(Biomass)는 2013년 기준 국내 발생량이 8,909,489 ton으로 총량의 약 48\% (4,276,554 ton)는 볏짚, $20 \%(1,782,898$ ton)는 왕겨가 차지하고 있다. 이들 가운데 약 60 80\%가 퇴비 또는 가축 사료 등으로 쓰 여 폐기되지 않고 이용되는 비율 또한 높은 것으로 조사 되 었다. 그러나 이는 단순 용도로 사용되는 것에 불과하며 보 다 부가가치를 창출할 수 있는 방안을 모색할 필요가 있다. 근래에 환경선진국들은 대량으로 발생하는 농업 부산물을 이용하여 바이오 에탄올, 바이오가스, 바이오차 등 바이오 매스를 활용한 기술들을 연구·개발 중에 있으며, 최근까지 국내에서도 바이오매스(Biomass)를 원료로 하여 제조된 바 이오차(BC, biochar)를 활용한 연구가 진행되고 있다. ${ }^{7,8)}$

바이오차(BC, biochar)는 바이오매스(biomass)를 산소가 제한된 조건에서 열분해(pyrolysis)하여 제조하는 탄화 물 질이다. ${ }^{9}{ }^{9}$ 바이오차를 토양에 적용 시 토질 개선에 탁월한 역할을 수행하며 농업생산성 및 $\mathrm{pH}$, 보수력, 양이온 교환 능력 등의 상승을 불러온다. ${ }^{10)}$ 또한 대기 중 온실가스 증가 에 따른 기후변화 문제의 해결책의 하나인 탄소격리 효과 도 보고된 바 있다. ${ }^{11)}$ 바이오차는 다공성의 구조로 이루어 져 있어 비표면적이 넓고, 방향족 화합물과 $\mathrm{C}=\mathrm{O}, \mathrm{C}=\mathrm{C}$ 등 의 작용기(Functional group)를 다수 함유하고 있으며, 이러 한 특성은 중금속, 유기 오염물 등의 흡착에 유리하다. 바 이오차의 특성은 제조공정에서의 반응 조건과 투입 원료에 따라 상이하기 때문에 연구 분야에 따라 적절한 제조방식 과 원료의 선택이 요구된다. ${ }^{12 ~ 14)}$

따라서, 본 연구에서는 알루미늄( $\mathrm{Al})$ 생산을 위한 보크 사이트(Bauxite) 제련 공정의 부산물인 레드머드(RM, red mud)와 농업 부산물 바이오매스(Biomass)인 왕겨(Rice husk) 를 원료로 이용하여 제조된 바이오차를 개량제로서 토양에 적용하여 토질을 개선하였다. 그에 따라 산업 폐기물인 레 드머드의 토양 적용 가능성을 조사하였고, 바이오차를 접 목하여 작물을 생육함으로써 실제 농경지에서의 생육환경 개선 가능성을 연구하였다. 또한, 이 연구는 미처리 되고 있는 산업 폐기물과 농업 생산과정에서 발생한 바이오매스 를 토양에 환원시킴으로써 폐기물 자원순환, 폐기물 처리
비 절감 등에 기여하고자 수행되었다.

\section{2. 연구방법}

\section{1. 실험재료}

\subsection{1. 토양 시료}

토양 시료는 나주시 일대의 임야와 농경지에서 채취되었 다. 토양은 협잡물을 제거하고 실온에서 풍건한 뒤 $10 \mathrm{mesh}$ $(<2 \mathrm{~mm})$ 이하로 체거름(sieving)하여 사용하였다.

\subsection{2. 레드머드(RM, red mud)}

보크사이트 제련 부산물인 레드머드는 전라남도에 위치 한 $\mathrm{K}$ 사에서 발생한 것을 사용하였다. 보크사이트에는 다량 의 철산화물이 존재하므로 레드머드는 붉은색을 띠게 된 다. $\mathrm{pH}$ 는 11 이상으로 강알칼리성을 지녔으며 막자사발을 이용하여 분쇄하고 체거름(100 mesh) 후 사용하였다.

\subsection{3. 바이오차(BC, biochar)}

바이오차는 전남 장흥군의 농가에서 발생한 왕겨 $(\mathrm{RH}$, rice husk)를 이용하였고 $400 \pm 5^{\circ} \mathrm{C}$ 에서 약 30 분간 탄화하 여 제조(BC400)하였다. 제조된 바이오차는 실온에서 풍건 후 파쇄하여 $60 \mathrm{mesh}$ 이하로 체거름 후 사용하였다.

\subsection{4. 시료 배합}

개량제인 레드머드(RM)와 바이오차(BC)는 산성토양을 대조구(Control)로 하여 처리구1 $\left(\mathrm{T} 1,1_{\mathrm{Soil}}: 0.01_{\mathrm{RM}}\right)$, 처리구 2 (T2, $1_{\text {Soil }}: 0.01_{\mathrm{RM}}: 0.02_{\mathrm{BC}}$ )로 구분하고 각각을 중량비 $(\mathrm{w}: \mathrm{w})$ 로 혼합하였다.

\section{2. 실험방법}

\subsection{1. 이화학적 특성 분석}

산성토양과 배합된 시료는 HDPE (High Density Polyethylene) 용기에 담아 시료의 약 $30 \mathrm{wt} \%$ 에 준하는 증류수를 첨가하고 3 일간의 수화반응(Hydration reaction)을 거친 후 분석에 사용되 었다. 모든 분석은 3 반복으로 진행되었다.

$\mathrm{pH}$ 와 $\mathrm{EC}$ 측정은 농촌진흥청 국립농업과학원의 토양화학 분석법(2010)에 준하여 시료 : 증류수 $=1: 5(\mathrm{w}: \mathrm{v})$ 비율로 혼합하고 약 1 시간 교반 후 $\mathrm{pH}, \mathrm{EC}$ meter를 이용하여 측정 하였다. 염류농도(EC)는 다음과 같은 식을 통하여 산출하 였다.

염류농도 $(\mathrm{EC}, \mathrm{dS} / \mathrm{m})=[$ 증류수 $(\mathrm{ml}) /$ 시료무게 $(\mathrm{g}) \times$ 측정값 $(\mathrm{mmhos} / \mathrm{cm}) \times$ 온도보정계수]

치환성 양이온(Exchangeable cations)은 시료에 $1 \mathrm{M}-\mathrm{NH}_{4} \mathrm{OAc}$ $(\mathrm{pH} 7)$ 를 $1: 5(\mathrm{w}: \mathrm{v})$ 비율로 가하고 30 분 동안 진탕 후 여과하여 
Table 1. Physicochemical properties of soil used in the experiment.

\begin{tabular}{|c|c|c|c|c|c|c|c|c|c|c|c|}
\hline \multicolumn{3}{|c|}{ Particle size distribution (\%) } & \multirow{2}{*}{$\begin{array}{l}\text { Soil } \\
\text { texture }\end{array}$} & \multirow{2}{*}{$\mathrm{pH}$} & \multirow{2}{*}{$\begin{array}{c}E C \\
(d S / m)\end{array}$} & \multirow{2}{*}{$\begin{array}{l}\mathrm{OM} \\
(\mathrm{g} / \mathrm{kg})\end{array}$} & \multirow{2}{*}{$\begin{array}{l}\text { Avail. } \mathrm{P}_{2} \mathrm{O}_{5} \\
(\mathrm{mg} / \mathrm{kg})\end{array}$} & \multicolumn{4}{|c|}{$\begin{array}{c}\text { Exchangeable cations } \\
(\mathrm{cmol} / \mathrm{kg})\end{array}$} \\
\hline Sand & Silt & Clay & & & & & & $\mathrm{Mg}^{2+}$ & $\mathrm{K}^{+}$ & $\mathrm{Ca}^{2+}$ & $\mathrm{Na}^{+}$ \\
\hline 59.8 & 26.0 & 14.2 & Sandy loam & 4.84 & 0.20 & 7.8 & 5.14 & 1.95 & 0.12 & 0.74 & 0.09 \\
\hline
\end{tabular}

Table 2. Physicochemical properties of red mud used in the experiment.

\begin{tabular}{|c|c|c|c|c|c|c|c|}
\hline \multirow{2}{*}{$\mathrm{pH}$} & \multirow{2}{*}{$\begin{array}{c}E C \\
(\mathrm{dS} / \mathrm{m})\end{array}$} & \multirow{2}{*}{$\begin{array}{l}\mathrm{OM} \\
(\mathrm{g} / \mathrm{kg})\end{array}$} & \multirow{2}{*}{$\begin{array}{l}\text { Avail. } \mathrm{P}_{2} \mathrm{O}_{5} \\
(\mathrm{mg} / \mathrm{kg})\end{array}$} & \multicolumn{4}{|c|}{$\begin{array}{l}\text { Exchangeable cations } \\
(\mathrm{cmol} / \mathrm{kg})\end{array}$} \\
\hline & & & & $\mathrm{Mg}^{2+}$ & $\mathrm{K}^{+}$ & $\mathrm{Ca}^{2+}$ & $\mathrm{Na}^{+}$ \\
\hline 11.54 & 23.51 & 1.7 & 83.1 & 21.62 & 21.62 & 293.11 & $1,528.0$ \\
\hline
\end{tabular}

$\mathrm{ICP}-\mathrm{OES}$ 를 이용하여 치환성 양이온 $(\mathrm{Ca}, \mathrm{Mg}, \mathrm{K}, \mathrm{Na})$ 을 정량 하였다. 양이온교환용량(CEC)는 토양 및 식물체 분석법의 brown법에 따라 $\mathrm{Mg}+\mathrm{K}+\mathrm{Ca}+\mathrm{Na}+\mathrm{H}$ 이온의 합으로 산출하였 다. 시료의 입도 분석은 KS F 2302 한국표준정보망, 흙의 입도 시험방법에 따라 분석하였다. 유기물(organic matter)은 Tyurin법에 따라 시료에 $0.4 \mathrm{~N}$ 중크롬산칼리황산혼합액을 가하 고 $200^{\circ} \mathrm{C}$ 전열판에서 가열한 후 $\mathrm{H}_{3} \mathrm{PO}_{4}$ 과 디페닐아민용액을 가하고 $0.2 \mathrm{~N}$ 황산제 1 철암모늄 용액으로 종말점까지 적정하였 다. 유효인산(Available $\left.\mathrm{P}_{2} \mathrm{O}_{5}\right)$ 은 Lancaster법에 준하여 시료에 침출액을 가하고 여과 후 조작액과 발색시약을 넣고 발색 후 UV-Vis을 이용하여 분석하였다. 시료의 표면분석은 SEM, 작용기는 FT-IR, 화합물 조성은 XRF 분석을 실시하였다.

\subsection{2. 포트 실험(pot experiment)}

종자의 파종은 농촌진흥청(발간등록번호 11-1390804-00 0312-01)의 잎채소 매뉴얼에 준하여 진행되었다. 실험 작물 은 청치마 상추이며, 가로 $\times$ 세로 $\times$ 높이 $=50 \mathrm{~cm} \times 35 \mathrm{~cm}$ $\times 20 \mathrm{~cm}$ 인 포트에서 생육하였다. 포트 내에는 2.1.4에 상 술한 바와 같이 혼합된 세 집단(control, T1, T2)의 시료를 작토층의 깊이(논, 밭 $15 \mathrm{~cm})$ 이상 처리하였다. 상추 종자는 약 $10 \mathrm{~cm}$ 간격으로 $1 \sim 2 \mathrm{~cm}$ 깊이의 구멍을 낸 후, 2 립씩 파종하였다. 상추의 발아-생육-수확 과정은 옥외에서 진행 되었다. 발아 후 싹은 재식 간격 $(15 \times 15 \mathrm{~cm})$ 으로 솎아주었 다. 생육 과정의 기상 조건은 온도 $16 \sim 22^{\circ} \mathrm{C}$, 습도 $50 \sim 70 \%$ 이며, 파종 후 약 4주간 생육하여 생육지표를 조사하였다.

수확한 작물은 전수조사를 통하여 종자 당 3장의 상추잎 을 표본으로 추출하였다. 생육지표 조사 항목은 엽장 (length), 엽폭(width), 생체중(weight) 및 건체중(dry weight) 을 조사하여 레드머드와 바이오차의 처리 유무에 따라 각 각의 지표를 비교 분석하였다.

엽장은 상추잎의 전체 길이를 측정하였고, 엽폭은 상추 외부의 가장 큰 너비를 측정하였다. 생체중은 수확한 상추 외부의 토사나 이물질을 제거한 후 무게를 측정하였다. 건체 중은 생체중을 측정한 상추를 정제수로 수차례 세척 후 dry
Table 3. Chemical composition from XRF analysis of red mud.

\begin{tabular}{ccccccc|c}
$\begin{array}{c}\text { Compositon } \\
(\%)\end{array}$ & $\mathrm{Na}_{2} \mathrm{O}$ & $\mathrm{Fe}_{2} \mathrm{O}_{3}$ & $\mathrm{Al}_{2} \mathrm{O}_{3}$ & $\mathrm{SiO}_{2}$ & $\mathrm{TiO}_{2}$ & $\mathrm{CaO}$ \\
& 10.1 & 29.5 & 23.4 & 19.8 & 5.7 & 5.4 \\
\hline
\end{tabular}

oven $\left(50^{\circ} \mathrm{C}\right)$ 에서 항량이 될 때까지 건조하여 측정되었다.

\subsection{3. 중금속 함량 분석}

토양의 중금속 분석은 환경부 고시 토양오염공정시험기 준 금속류-유도결합플라즈마-원자발광분광법(ES 07400.2b) 에 따라 분석하였다. 시료 $1.5 \mathrm{~g}$ 을 $100 \mathrm{~mL}$ 테플론 분해용 기에 넣고 $\mathrm{HCl}: \mathrm{HNO}_{3}=3: 1(\mathrm{v}: \mathrm{v})$ 의 비율로 혼합한 왕 수를 가하여 2 시간 상온에서 정치한다. 이후 포집관과 분 해용기를 결합한 뒤 포집관에 $0.5 \mathrm{M}$ 질산 $\left(\mathrm{HNO}_{3}\right) 7.5 \mathrm{ml}$ 를 넣고 $90^{\circ} \mathrm{C}$ 에서 2 시간 가열하여 시료를 분해하였다. 분해가 완료되면 여과 후 ICP-OES를 이용하여 중금속 함량을 분 석하였다. 식물체의 중금속 분석은 흑연블럭 시료전처리 매뉴얼에 따라 시료 $0.5 \mathrm{~g}$ 에 질산 $15 \mathrm{ml}$ 와 분해를 촉진하 기 위한 과산화수소를 $0.5 \mathrm{ml}$ 첨가한 후 $240^{\circ} \mathrm{C}$ 에서 4시간 분해하여 여과 후 ICP-OES로 분석하였다.

\subsection{4. 통계 분석}

분석된 데이터는 SPSS statistics 23을 이용하여 일원배치 분산분석(one-way ANOVA)을 수행하고, $95 \%$ 유의 수준에 서 사후검정(scheffe test)을 실시하여 집단 간의 유의성을 분석하였다.

\section{3. 결과 및 고찰}

\section{1. 토양 및 개량제 분석결과}

본 연구에 사용된 토양의 이화학적 분석 결과는 Table 1 과 같다. 토양 $\mathrm{pH}$ 는 4.84로 나타났으며 모래와 점토 함량 은 각각 $59.8 \%, 14.2 \%$ 로 사양토로 분석되었고 유기물 함량 은 $7.8 \mathrm{~g} / \mathrm{kg}$ 이었다. 레드머드의 $\mathrm{pH}$ 는 11.54 로 강염기를 띠 


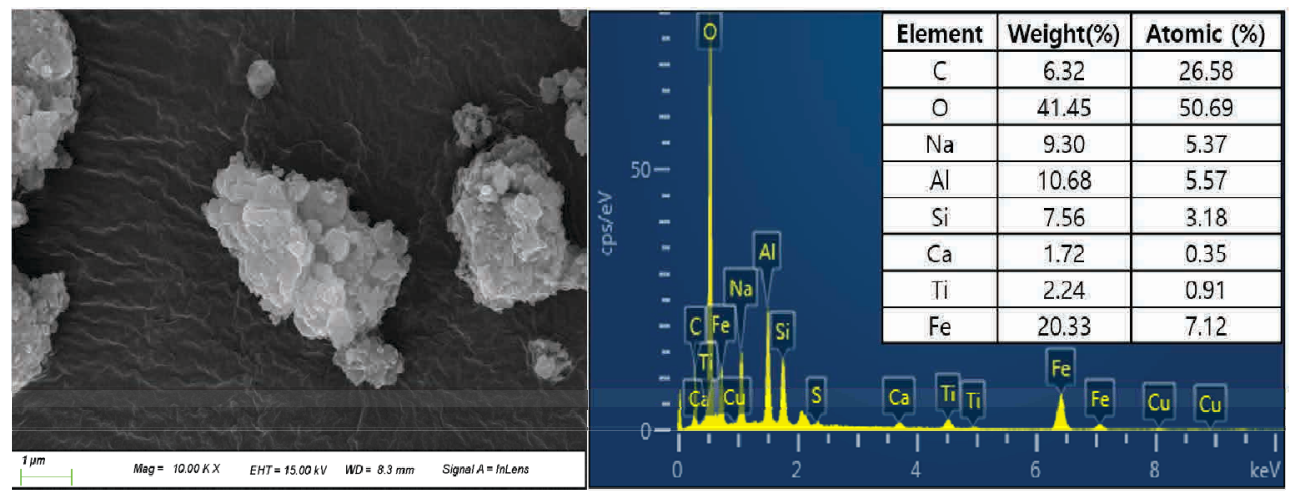

Fig. 1. SEM-EDS analysis results of red mud.

Table 4. Reaction condition and physicochemical properties of produced biochar.

\begin{tabular}{|c|c|c|c|c|c|c|c|c|c|}
\hline \multicolumn{2}{|c|}{ Reaction condition } & \multirow[t]{2}{*}{$\mathrm{pH}$} & \multirow{2}{*}{$\begin{array}{c}\text { EC } \\
(\mathrm{dS} / \mathrm{m})\end{array}$} & \multirow{2}{*}{$\begin{array}{l}\text { OM } \\
(g / k g)\end{array}$} & \multirow{2}{*}{$\begin{array}{l}\text { Avail. } \mathrm{P}_{2} \mathrm{O}_{5} \\
(\mathrm{mg} / \mathrm{kg})\end{array}$} & \multicolumn{4}{|c|}{$\begin{array}{c}\text { Exchangeable cations } \\
(\mathrm{cmol} / \mathrm{kg})\end{array}$} \\
\hline Temp. $\left({ }^{\circ} \mathrm{C}\right)$ & Time (min) & & & & & $\mathrm{Mg}^{2+}$ & $\mathrm{K}^{+}$ & $\mathrm{Ca}^{2+}$ & $\mathrm{Na}^{+}$ \\
\hline $400 \pm 5$ & 30 & 7.65 & 2.03 & 122.3 & 877.5 & 23.31 & 203.79 & 21.59 & 53.77 \\
\hline
\end{tabular}

었다. 염류농도(EC)는 $23.51 \mathrm{dS} / \mathrm{m}$ 로 토양에 비해 매우 높 았으며, 유기물 햠량은 $1.7 \mathrm{~g} / \mathrm{kg}$ 으로 낮은 편이었다(Table 2). 화학적 조성을 알아보기 위한 레드머드의 XRF 분석 결 과는 Table 3와 같다. 레드머드의 성분은 대부분이 $\mathrm{Fe}$ 와 $\mathrm{Al}, \mathrm{Si}, \mathrm{Na}, \mathrm{Ti}, \mathrm{Ca}$ 등으로 구성되어 있었으며, 이외에도 소 량의 희소성 유가금속을 함유하고 있는 것으로 알려져 있 다. ${ }^{4)}$ 이러한 레드머드의 화학적 조성은 여러 선행 연구 결 과들과 유사함을 보였다. $\mathrm{EDS}$ 성분분석 결과(Fig. 1) 보크 사이트 제련 후에도 알루미늄이 약 $10 \%$ 함유하고 있는 것 으로 조사되었고 $\mathrm{O}, \mathrm{Fe}, \mathrm{Si}, \mathrm{Na}$ 등도 잔류하고 있어 $\mathrm{XRF}$ 분석결과와 잔류 성분들이 유사하였다. 레드머드의 조성 자체는 보크사이트 광물의 성분과 공정에 따라 달라질 수 있다. ${ }^{6,15 ~ 17)}$

제조된 바이오차(BC400)의 이화학적 분석결과 $\mathrm{pH}$ 는 7.65 로 약염기성을 띄었다. 한 문헌에 따르면, 바이오차의 $\mathrm{pH}$ 는 열분해에 의한 산성 작용기의 점진적인 손실과 알칼리 성 염의 농축으로 인해 증가하며 일반적으로 열분해 온도 와 시간에 비례한다고 보고하였다. ${ }^{1819)}$ 그러므로 본 연구에 서, 바이오차의 낮은 $\mathrm{pH}$ 는 상대적으로 낮은 열분해 온도와 짧은 열분해 시간이 원인으로 판단된다. 바이오차의 염류 농도는 $2.03 \mathrm{dS} / \mathrm{m}$ 로 토양보다는 높았으나 레드머드보다는 낮았다. 유기물 함량은 $122.3 \mathrm{~g} / \mathrm{kg}$ 으로 토양이나 레드머드 에 비해 높은 함량으로 분석되었다(Table 4).

왕겨(RH, rice husk)와 바이오차(BC400)의 작용기(functional group)를 조사하기 위해 FT-IR 분석을 실시한 결과(Fig.2) 열 분해 시 peak가 완만해지거나 감소하는 현상이 관찰되었는데 이는 고온으로 인한 작용기들의 감소에 기인한 것으로 판단 된다. Peak 해석 결과 $3,304 \mathrm{~cm}^{-1}(\mathrm{RH})$ 에서 $\mathrm{O}-\mathrm{H}, 2,925 \mathrm{~cm}^{-1}$

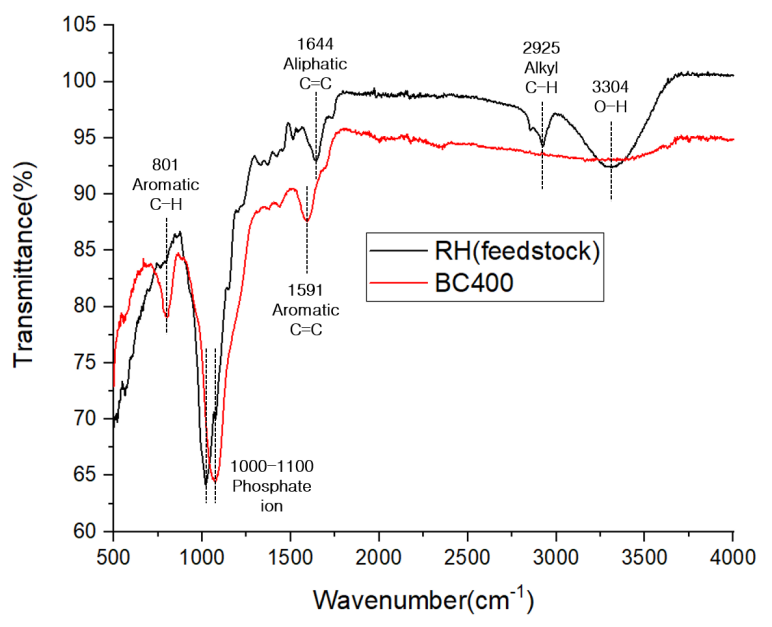

Fig. 2. FT-IR spectra of rice husk (RH), produced biochar at $400^{\circ} \mathrm{C}$ (BC400).

(RH)에서 alkyl C-H peak가 관찰되었고 $\mathrm{BC} 400$ 에서는 해당 peak가 관찰되지 않았다. $1,644 \mathrm{~cm}^{-1}(\mathrm{RH})$ 에서 aliphatic $\mathrm{C}=\mathrm{C}$ peak, $1,591 \mathrm{~cm}^{-1}$ (BC400)에서 aromatic $\mathrm{C}=\mathrm{C}$ peak가 관찰되어 방향족화(aromatization)가 진행된 것으로 판단된다. 마찬가 지로 $801 \mathrm{~cm}^{-1}$ (BC400) peak에서 $\mathrm{RH}$ 에는 존재하지 않던 aromatic C-H bond가 생성되어 열분해 과정에서 방향족화가 이루어졌다고 볼 수 있다. 이는 이전 연구들과 같이 바이오매 스를 강열하여 바이오차를 생산하는 과정에서 특정 작용기가 휘발되거나 생성되는 현상과 유사성을 보였다. 또한 1,019 $\mathrm{cm}^{-1}$ (RH)와 $1,073 \mathrm{~cm}^{-1}$ (BC400)에서 phosphate ion peak가 관찰되었다. 일반적으로 phosphate ion peak는 1,000 1,100 $\mathrm{cm}^{-1}$ 에서 나타나며 강열 후에도 파수(wave number)의 변화만 존재하였을 뿐 열분해로 인해 변하거나 휘발되는 현상은 발 


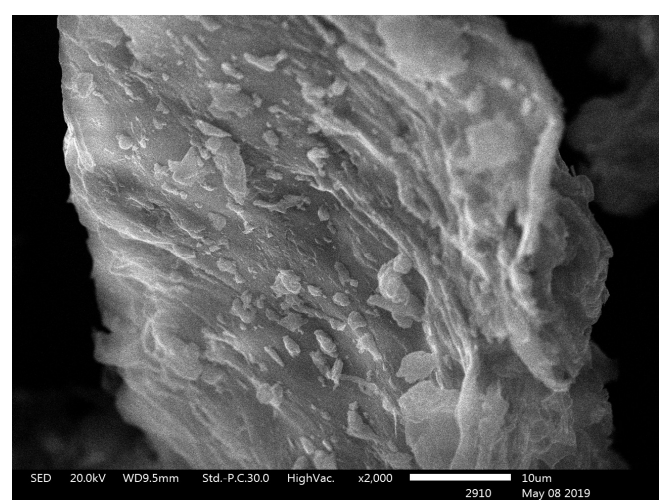

(A)

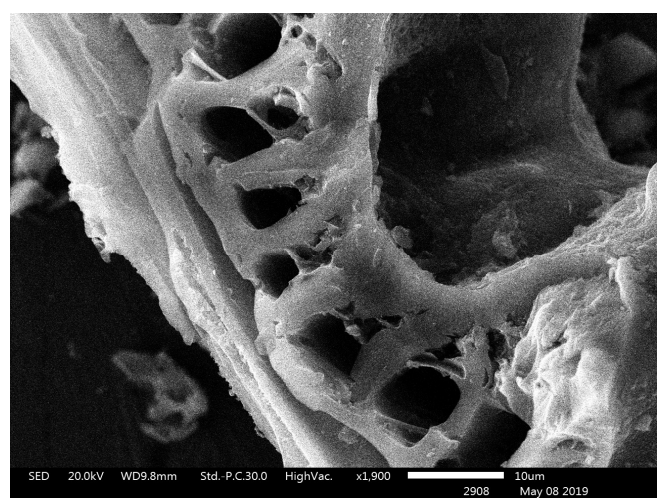

(B)

Fig. 3. SEM images of (A) rice husk (RH), (B) produced biochar at $400^{\circ} \mathrm{C}(\mathrm{BC} 400)$.

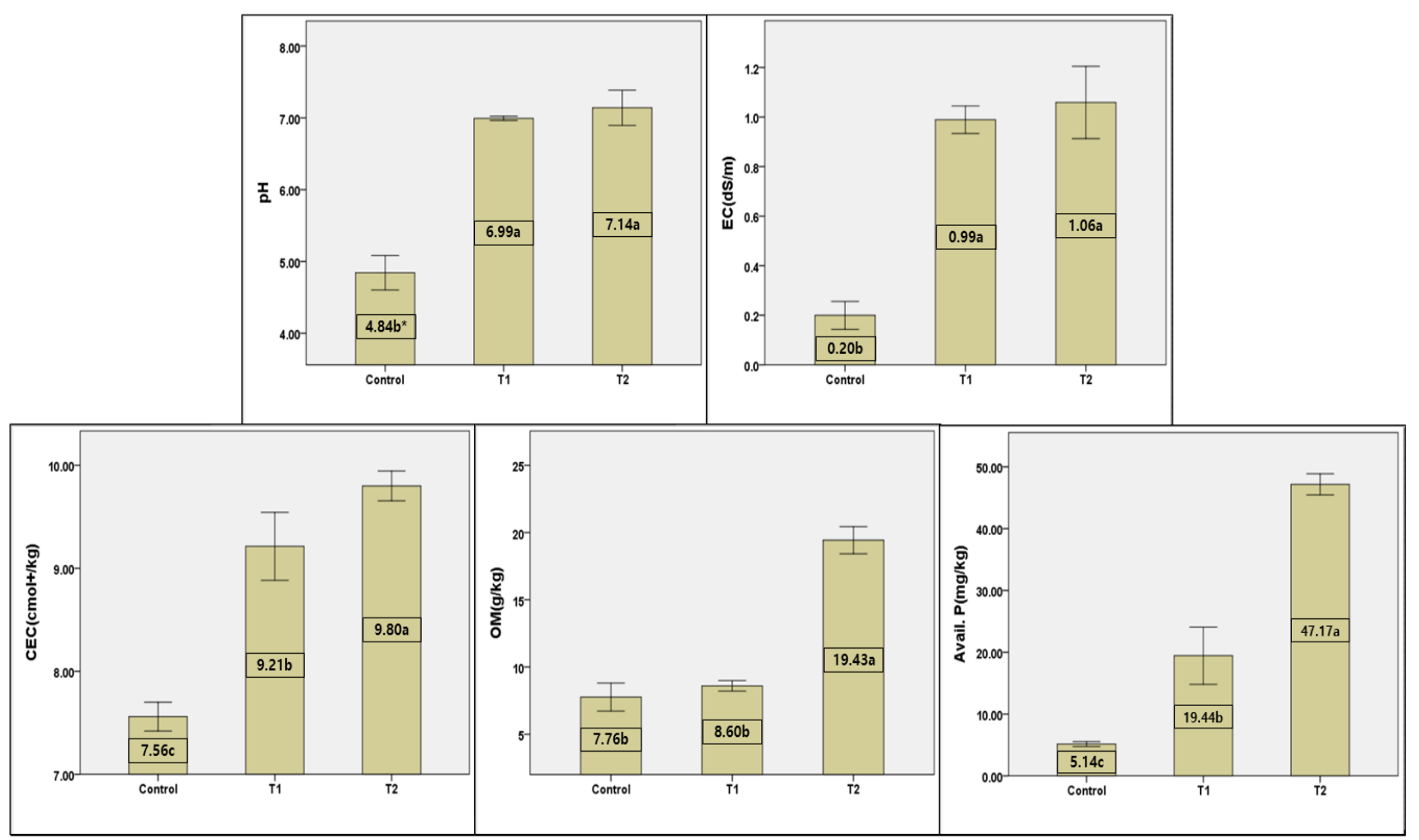

Fig. 4. Physicochemical properties of treated soil (The same letters are not significantly different at $p<0.05$ ).

견되지 않은 것으로 나타났다. 결과적으로 이는 선행 연구와 유사하게 왕겨 자체에 인산이온이 함유되어 있는 것으로 판 단된다. ${ }^{18-21)}$

왕겨(RH)와 제조된 바이오차(BC400)의 SEM image는 Fig. 3과 같다. 왕겨는 상대적으로 매끄러운 표면을 지니고 있으며, 이와 달리 바이오차(BC400)는 여러 공극들이 관찰 되었다. 이는 열분해 과정에서 고온으로 인한 작용기들의 감소와 휘발성 물질이 이탈되었을 것으로 판단된다. 특히 탈수산작용(dehydroxylation)에 의해 방출된 물 분자가 공 극을 형성하는 역할을 하여 다공성이 증대되었다는 연구결 과가 보고된 바 있다. ${ }^{18)}$ 또한 열분해 온도의 상승은 비표면 적을 증가시키는 것으로 알려져 있는데 이는 aliphatic alkyl
이나 ester group의 분해 등에 기인한다는 연구결과도 보고 되었다. ${ }^{22)}$

\section{2. 처리구 토양 분석결과}

산성 토양을 적정 $\mathrm{pH}$ 로 중화하고자 레드머드와 바이오 차를 처리한 결과는 Table 5 와 같다. $\mathrm{pH}$ 는 레드머드와 바 이오차 첨가량에 따라 상승하였다. 레드머드는 $1 \%$ 처리 시 중성에 가까운 값 $(\mathrm{pH}$ 6.99)까지 상승한 반면, 바이오차는 전반전인 상승폭이 낮아 산성화된 토양을 중화시키기에 다 소 많은 양의 바이오차가 처리 되어야 할 것으로 판단된다. 레드머드와 바이오차를 함께 처리한 토양(T2)의 $\mathrm{pH}$ 는 7.14 로 레드머드만 처리된 토양(T1)에 비해 평균값은 상승하였 
Table 5. $\mathrm{pH}$ and EC of treated soil using red mud and biochar.

\begin{tabular}{ccc} 
Soil & pH & EC(dS/m) \\
Control & $4.84 d^{*}$ & $0.20 \mathrm{e}$ \\
RM 1\% & $6.99 \mathrm{c}$ & $0.98 \mathrm{~d}$ \\
RM 2\% & $7.31 \mathrm{~b}$ & $1.41 \mathrm{c}$ \\
RM 3\% & $7.43 \mathrm{~b}$ & $1.95 \mathrm{~b}$ \\
RM 5\% & $8.21 \mathrm{a}$ & $2.89 \mathrm{a}$ \\
\hline Control & $4.84 \mathrm{c}$ & $0.20 \mathrm{~d}$ \\
BC 1\% & $5.18 \mathrm{~b}$ & $0.23 \mathrm{~cd}$ \\
BC 2\% & $5.23 \mathrm{ab}$ & $0.25 \mathrm{c}$ \\
BC 3\% & $5.29 \mathrm{ab}$ & $0.30 \mathrm{~b}$ \\
BC 5\% & $5.35 \mathrm{ab}$ & $0.35 \mathrm{a}$ \\
\hline
\end{tabular}

* Same letters are not significantly different $(p<0.05)$



Fig. 5. Relationship between the electrical conductivity and $\mathrm{Na}^{+}$.

으나 통계적인 유의성은 없었다(Fig. 4). 일반적으로 토양 관리에 있어 적정 $\mathrm{pH}$ 는 6 7로 이 값은 식물의 양분 유효 도 및 미생물 활성 등에 적절한 값으로 알려져 있다. 이에 따라 $\mathrm{T} 1$ 과 $\mathrm{T} 2$ 의 $\mathrm{pH}$ 는 작물 생육에 적정한 수준인 것으로 판단된다. 염류농도(EC)는 토양의 전기전도도를 지표로 이 용하며, 일반적으로 봄철과 여름철의 기온 상승에 의해 토 양표면에 염류가 집적된다. 과도한 염류집적은 삼투압을 증가시켜 식물체의 수분 흡수를 방해 하여 식물체의 생장 에 영향을 미치며, 생리적 장해를 일으키기도 한다. 고농도 의 염류는 식물체를 고사에 이르게 할 수 있다. ${ }^{23)}$

$\mathrm{EC}$ meter로 측정하여 염류농도(EC)를 산출한 결과, 대조 구(control)에서는 $0.20 \mathrm{dS} / \mathrm{m}, \mathrm{T} 1$ 과 $\mathrm{T} 2$ 에서는 각각 0.99 , $1.06 \mathrm{dS} / \mathrm{m}$ 로 나타났다(Fig. 4). 레드머드와 바이오차를 첨가 한 T1과 T2에서 토양 염류농도가 증가한 것으로 나타났지 만 대조구를 제외한 처리구 간의 유의성은 없었다. 염류농 도 증가의 원인은 질산태질소 $\left(\mathrm{NO}_{3}-\mathrm{N}\right)$ 및 나트륨 이온 $\left(\mathrm{Na}^{+}\right)$ 농도와 관련이 있는 것으로 알려져 있으며, 일부 연구에서 는 염류농도와 나트륨 이온 $\left(\mathrm{Na}^{+}\right)$간의 상관관계 분석에서
Table 6. CEC and exchangeable cation of treated soil.

\begin{tabular}{|c|c|c|c|c|c|}
\hline Soil & CEC & $\mathrm{Mg}$ & K & $\mathrm{Ca}$ & $\mathrm{Na}$ \\
\hline & \multicolumn{5}{|c|}{ 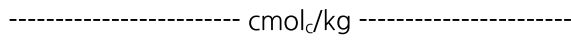 } \\
\hline Control & $7.56 \mathrm{e}$ & $2.00 a$ & $0.15 c$ & $0.69 \mathrm{e}$ & $0.04 \mathrm{e}$ \\
\hline RM $1 \%$ & $9.21 d$ & $1.91 a b$ & $0.16 c$ & $2.54 d$ & $2.03 d$ \\
\hline RM 2\% & $11.56 \mathrm{c}$ & $1.90 a b$ & $0.17 c$ & $4.71 c$ & $4.12 c$ \\
\hline RM 3\% & $14.54 b$ & $1.90 \mathrm{ab}$ & $0.21 b$ & $6.38 b$ & $6.05 b$ \\
\hline RM 5\% & $20.70 a$ & $1.88 \mathrm{~b}$ & $0.24 a$ & $9.96 a$ & $8.62 a$ \\
\hline Control & $7.56 \mathrm{e}$ & $2.00 a$ & $0.15 \mathrm{e}$ & $0.69 c$ & $0.04 a$ \\
\hline BC $1 \%$ & $7.80 \mathrm{~d}$ & $2.01 a$ & $0.22 d$ & $0.76 b$ & $0.04 a$ \\
\hline BC $2 \%$ & $7.97 \mathrm{c}$ & $2.01 a$ & $0.29 c$ & $0.79 a b$ & $0.04 a$ \\
\hline BC $3 \%$ & $8.16 b$ & $2.02 \mathrm{a}$ & $0.38 b$ & $0.80 a b$ & $0.05 a$ \\
\hline BC $5 \%$ & $8.35 a$ & $1.99 a$ & $0.49 a$ & $0.83 a$ & $0.05 a$ \\
\hline Opitmal range ${ }^{28)}$ & $10 \sim 15$ & $1.5 \sim 2.0$ & $0.3 \sim 0.8$ & $5.0 \sim 6.0$ & - \\
\hline
\end{tabular}

* Same letters are not significantly different $(p<0.05)$

높은 정의 상관관계 $(\mathrm{R}=0.973)$ 를 보고하였다. ${ }^{23,24)}$ 본 연구에 서는 레드머드 첨가 시에 급격한 염류농도의 상승이 관찰 되었는데, 레드머드 첨가량 $(\mathrm{RM} \mathrm{n} \%, \mathrm{n}=1,3,5,7,10)$ 에 따른 $\mathrm{Na}^{+}$농도와 염류농도의 상관분석을 실시한 결과 $\mathrm{R}=0.978$ 로 유의한 정 $(+)$ 의 상관관계가 존재하는 것으로 분석되었다 (Fig. 5). 결과적으로 레드머드가 고농도의 나트륨 이온 $\left(1,528.0 \mathrm{cmol}_{\mathrm{c}} / \mathrm{kg}\right)$ 을 함유하고 있어 염류농도 상승에 기여 한 것으로 판단된다. 한편, 작물생육에 적합한 염류농도는 $2.0 \mathrm{dS} / \mathrm{m}$ 이하로 알려져 있으며, ${ }^{25)}$ 레드머드 $1 \%$, 바이오차 $2 \%$ 처리한 $\mathrm{T} 2$ 에서 염류농도는 $1.06 \mathrm{dS} / \mathrm{m}$ 으로 조사되어 작 물에 염해 피해는 없을 것으로 판단된다.

양이온치환용량 $(\mathrm{CEC})$ 은 토양 입자가 양이온을 흡착할 수 있는 능력으로, 일정량의 토양 교질(Soil colloid)이 보유 하는 음전하의 총량과도 같다. $\mathrm{CEC}$ 는 토양 비옥도의 지표 중 의 하나이며, $\mathrm{CEC}$ 가 낮은 경우 비료를 첨가하여도 토양 완충 능력이 저하되어 비옥도의 유지가 어려울 수 있다. 본 연구에 서의 $\mathrm{CEC}$ 분석 결과 대조구(control)에서 $7.56 \mathrm{cmol}_{\mathrm{c}} / \mathrm{kg}$, $\mathrm{T} 1$ 과 $\mathrm{T} 2$ 에서 각각 $9.21,9.80 \mathrm{cmol}_{\mathrm{c}} / \mathrm{kg}$ 으로 유의하게 값이 증가하였지만(Fig.4), 국립농업과학원(NAAS, 2010)에서 권 장하는 작물 적정 $\mathrm{CEC}\left(10 \sim 15 \mathrm{cmol}_{\mathrm{c}} / \mathrm{kg}\right)$ 에는 미치지 못하 는 것으로 조사되었다. $\mathrm{CEC}$ 는 레드머드와 바이오차를 처 리함에 따라 그 값이 증가하였는데, 특히 레드머드에서 $\mathrm{CEC}$ 의 증가량이 큰 것으로 조사되었다(Table 6). 이는 강 알칼리성 물질인 레드머드의 투입으로 인한 $\mathrm{pH}$ 의 상승과 함께 유기교질의 $\mathrm{H}^{+}$이 해리되고 이에 따라 음전하의 양이 늘어나면서 $\mathrm{CEC}$ 의 증가로 이어진 것으로 판단된다. ${ }^{5)}$ 또한 레드머드는 토양에 비해 높은 함량의 치환성 $\mathrm{Ca}^{2+}$ 과 $\mathrm{Na}^{+}$ (각각 293.11, 1,528.0 $\mathrm{cmol}_{\mathrm{c}} / \mathrm{kg}$ )을 보유하고 있어 레드머드 로 처리된 토양의 $\mathrm{CEC}$ 를 높이는데 기여한 것으로 판단된다. 마찬가지로 바이오차를 처리한 토양에서 $\mathrm{CEC}$ 의 상승이 관 찰되었는데(Table 6), 이는 바이오차의 높은 유기물함량과 유 


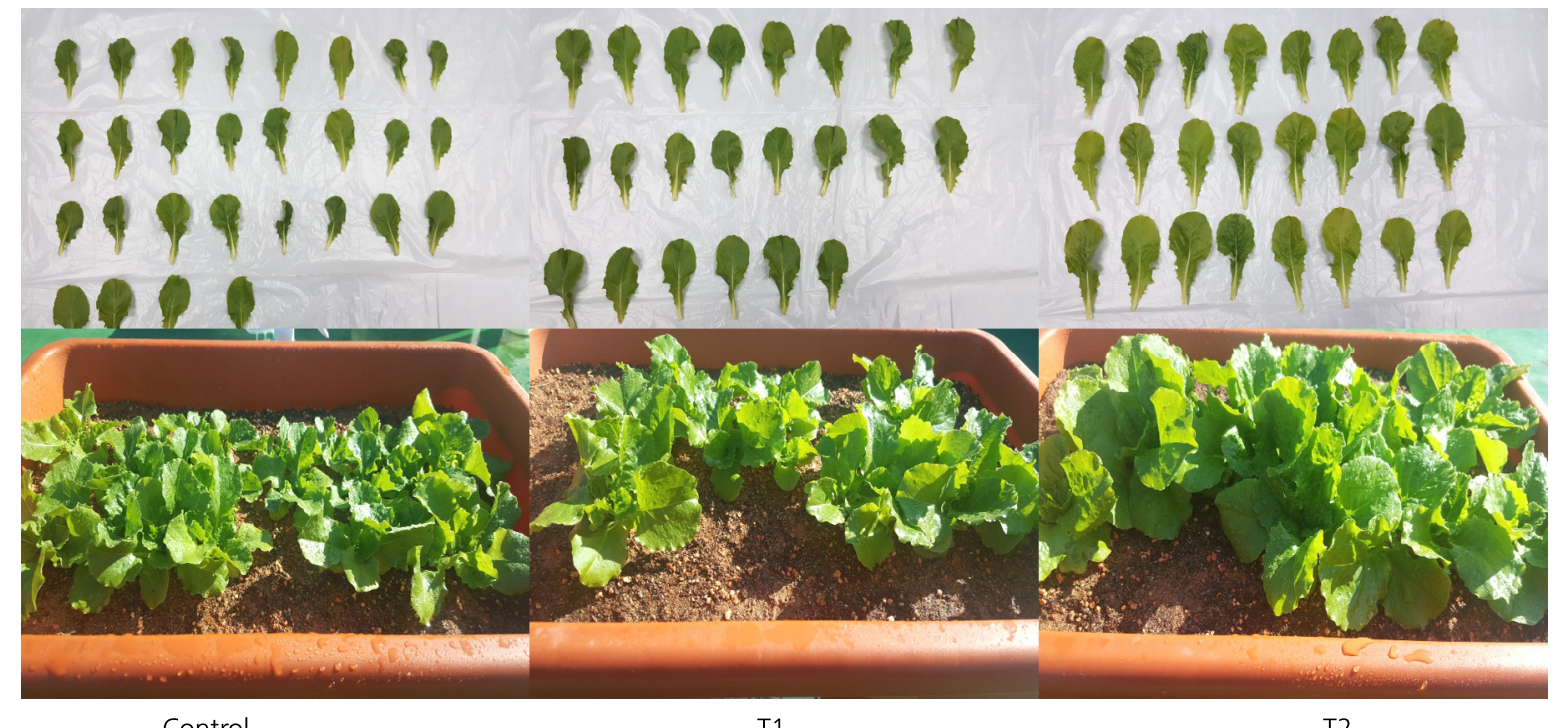

Control

T1

T2

Fig.6. Photographs of lettuce grown for 4 weeks in differently treated soil.

기물 내의 부식질(humus)이 음전하를 띠는 작용기(functional group)를 보유하고 있어 양이온치환 부위가 될 수 있기 때 문이다. 따라서 유기물을 함유한 개량제의 시용이 $\mathrm{CEC}$ 증 가에 영향을 미친 것으로 볼 수 있다. ${ }^{26,27)}$

한편 개량제 투입량에 따른 치환성 양이온 분석 결과 레 드머드는 $\mathrm{Na}^{+}$과 $\mathrm{Ca}^{2+}$ 의 농도가 유의하게 증가하였고, 바이 오차의 경우 $\mathrm{K}^{+}$과 $\mathrm{Ca}^{2+}$ 이 유의하게 증가하였다. 이는 치환 성 양이온 함량이 높은 레드머드와 바이오차의 첨가에 기 인하는 것으로 판단할 수 있다. 치환성 양이온은 작물 별로 권장량의 차이가 존재하며 상추의 경우 $\mathrm{Mg}^{2+}, \mathrm{K}^{+}, \mathrm{Ca}^{2+}$ 이 각각 2.0 2.5, 0.4 0.6, 6.0 7.0으로 알려져 있다. ${ }^{28)}$ 본 연구 에서 대조구 토양의 $\mathrm{Mg}^{2+}$ 은 $2.00 \mathrm{cmol}_{\mathrm{c}} / \mathrm{kg}$ 으로 적정 수준 이었으며 $\mathrm{K}^{+}, \mathrm{Ca}^{2+}$ 은 각각 $0.15 \mathrm{cmol}_{\mathrm{c}} / \mathrm{kg}, 0.69 \mathrm{cmol}_{\mathrm{c}} / \mathrm{kg}$ 으로 함량 미달로 조사되었다. 이에 따라 치환성 양이온을 적정 권장량으로 개선하기 위해 $\mathrm{Ca}^{2+}$ 은 레드머드를 $3 \%(6.38$ $\left.\mathrm{cmol}_{\mathrm{c}} / \mathrm{kg}\right)$ 이상, $\mathrm{K}^{+}$은 바이오차를 $5 \%\left(0.49 \mathrm{cmol}_{\mathrm{c}} / \mathrm{kg}\right)$ 가량 첨가해야 할 것으로 판단된다. 그러나 레드머드를 $3 \%$ 처리 시 $\mathrm{pH}$ 는 7.43 (Table 5)으로 적정범위를 크게 벗어나지 않 았으나 염류농도는 $1.95 \mathrm{dS} / \mathrm{m}$ (Table 5)로 기준치 $(2.0 \mathrm{dS} / \mathrm{m}$ ) 를 초과할 우려가 있는 것으로 나타났다. 이와 반대로 바이 오차는 $5 \%$ 처리 시에도 $\mathrm{pH}$ 는 5.35 , 염류농도는 $0.35 \mathrm{dS} / \mathrm{m}$ 로 나타나 레드머드에 비해 증가율이 매우 낮았다. 따라서 치환성 양이온을 개선하기 위해서는 작물 생육에 영향을 미칠 수 있는 토양의 이화학적 특성인 $\mathrm{pH}, \mathrm{EC}$ 등을 고려 하여 그에 따른 적절한 시용량을 산정해야 할 것으로 판단 된다.

유효인산 분석 결과 대조구(control)에서 $5.14 \mathrm{mg} / \mathrm{kg}$ 로 조 사되었고, T1과 T2에서 각각 $19.44,47.17 \mathrm{mg} / \mathrm{kg}$ 으로 개량 제 처리 시에 유의하게 증가하였다(Fig.4). 이는 레드머드
와 바이오차의 높은 유효인산 함량 때문인 것으로 볼 수 있으며 특히, 바이오차는 높은 유효인산을 보유하고 있는 데 이는 바이오차가 음전하를 띄고 있지만 유효인산의 흡 착량이 일반적인 토양의 유기물보다 뛰어나기 때문인 것으 로 판단된다. ${ }^{29)}$

\section{3. 포트 실험(pot experiment)}

4주간의 포트 실험 후 수확한 상추(Fig.6)와 생육지표 조 사결과는 Fig. 7과 같다. 엽장(length)의 경우 대조구(7.39 $\mathrm{cm})$ 에 비해 $\mathrm{T} 1(8.28 \mathrm{~cm})$ 에서는 약 $12 \%$ 증가되었고, $\mathrm{T} 2$ $(10.00 \mathrm{~cm})$ 에서는 약 $35 \%$ 증가되었다. 엽폭(width)의 경우 는 대조구 $(4.35 \mathrm{~cm})$ 대비 $\mathrm{T} 1(4.96 \mathrm{~cm})$ 에서 약 $14 \%$ 증가되 었고, T2 $(6.38 \mathrm{~cm})$ 에서는 $28 \%$ 증가되었다. 생체중(weight) 은 대조구가 $0.53 \mathrm{~g}, \mathrm{~T} 1$ 과 $\mathrm{T} 2$ 에서 $0.74 \mathrm{~g}, 1.01 \mathrm{~g}$ 으로 대조 구 대비 각각 $39 \%, 90 \%$ 증가되었다. 건체중(dry weight)은 대조구에서 $0.074 \mathrm{~g}, \mathrm{~T} 1$ 과 $\mathrm{T} 2$ 에서 $0.083 \mathrm{~g}, 0.100 \mathrm{~g}$ 으로 각 각 $12 \%, 35 \%$ 가량 증가되었다. 전반적으로 토양에 개량제 를 적용하였을 때 상추의 생육지표가 크게 증대되었다. 즉, 개량제 처리로 토양 이화학 특성 $(\mathrm{pH}, \mathrm{CEC}$ 등)이 변하였으 며, 작물 성장에 이로운 방향으로 토양이 개선된 것으로 사 료된다.

특히 토양의 $\mathrm{pH}$ 는 작물의 생육에 영향을 미치는 인자 중 의 하나이며 적정 $\mathrm{pH}$ 는 농작물 별로 상이하나 일반적으로 $\mathrm{pH}$ 가 6.0 7.0 일 때 가장 이상적인 것으로 알려져 있다. 토 양 $\mathrm{pH}$ 가 5.5 이하로 떨어지면 알루미늄이나 망간 이온에 의한 식물체의 독성이 나타나며, 토양에 다량의 알루미늄 이 존재하게 되면 식물체 뿌리의 성장과 대사 기능이 억제 되고 칼슘이나 마그네슘 등 토양 양분의 흡수를 저해한다. 또한 산성화된 토양은 질소 고정균, 유기물 분해, 양분의 


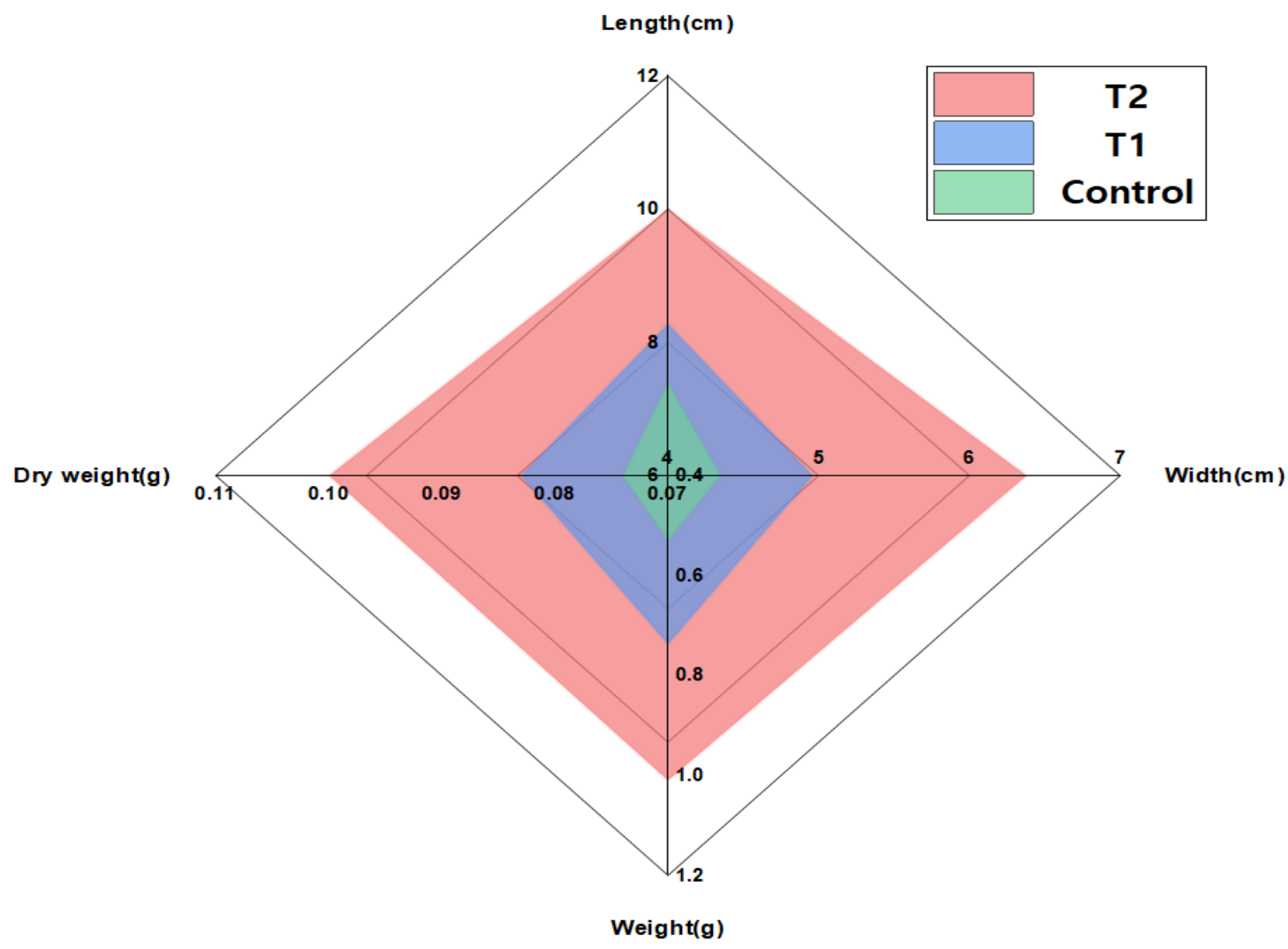

Fig. 7. Growth characteristics of lettuce in differently treated soil.

Table 7. Heavy metal concentration of treated soil and lettuce.

\begin{tabular}{|c|c|c|c|c|c|c|c|c|c|}
\hline & & $\mathrm{Ni}(100)^{*}$ & $\mathrm{~Pb}(200)$ & Zn (300) & As (25) & $\mathrm{Cd}(4)$ & $\mathrm{Cu}(150)$ & $\mathrm{Hg}(4)$ & $\mathrm{Al}$ \\
\hline \multicolumn{10}{|c|}{ 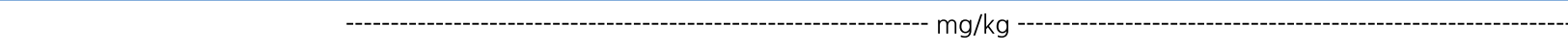 } \\
\hline \multirow{3}{*}{ Soil } & Control & $2.84 b^{*}$ & $17.71 a$ & $38.55 a$ & $3.63 a$ & $0.78 a$ & $5.86 a$ & $0.02 a$ & $13434 b$ \\
\hline & $\mathrm{T} 1$ & $3.37 a b$ & $16.85 a$ & $38.02 a$ & $3.57 a$ & $0.77 a$ & $5.69 a$ & $0.02 \mathrm{a}$ & $15463 a$ \\
\hline & $\mathrm{T} 2$ & $3.54 a$ & $16.66 a$ & $37.92 a$ & $3.63 a$ & $0.80 a$ & $6.03 a$ & $0.02 a$ & $15915 a$ \\
\hline \multirow{2}{*}{ Amendment } & RM & 73.32 & 18.12 & 113.50 & 7.73 & 4.66 & 38.67 & 0.03 & 64854 \\
\hline & $B C$ & 2.11 & 0.18 & 55.32 & 3.03 & N.D. & 10.56 & 0.01 & 13102 \\
\hline \multirow{3}{*}{ Lettuce } & Control & - & N.D. & - & - & $0.13 a$ & - & - & - \\
\hline & $\mathrm{T} 1$ & - & N.D. & - & - & $0.10 a$ & - & - & - \\
\hline & $\mathrm{T} 2$ & - & N.D. & - & - & $0.14 a$ & - & - & - \\
\hline
\end{tabular}

${ }^{*}()$ : standard value of heavy metals in the soil, same letters are not significantly different $(p<0.05)$

활용 등 유용성 미생물의 활동을 저해하며 알루미늄과 인 의 결합력을 강하게 하여 식물이 이용할 수 있는 유효인산 의 양을 감소시킨다. 반대로 염기성 물질의 시용으로 $\mathrm{pH}$ 가 상승하게 되면 토양의 양분유효도가 증가하며 토양 미생 물 활성을 증가 시킬 수 있다. ${ }^{30)}$ 본 연구에서 $\mathrm{T} 2$ 토양(RM $1 \%, \mathrm{BC} 2 \%$ 첨가)의 $\mathrm{pH}$ 는 4.84에서 $7.14, \mathrm{CEC}$ 는 7.56 $\mathrm{cmol}_{\mathrm{c}} / \mathrm{kg}$ 에서 $9.80 \mathrm{cmol}_{\mathrm{c}} / \mathrm{kg}$ 로 증가하여 대조구 토양에 비 해 개선되었다. 따라서 산성토양은 적절한 염기성 토양 개 량제를 처리하여 산도와 비옥도를 적절히 관리 하는 것이 중요할 것으로 판단된다.

\section{4. 중금속 분석}

토양 시료의 중금속 분석결과(Table 7), 토양환경보전법 토양오염 우려기준치와 비교하였을 때 레드머드의 $\mathrm{Cd}$ 농 도 $(4.66 \mathrm{mg} / \mathrm{kg})$ 는 전·답·과수원 등에 해당하는 1 지역 기준 $(4 \mathrm{mg} / \mathrm{kg})$ 을 초과하였다. 그러나 대조구 대비 $1 \%$ 의 레드머 드를 첨가한 $\mathrm{T} 1$ 과 $\mathrm{T} 2$ 의 경우 $\mathrm{Cd}$ 농도는 각각 $0.77 \mathrm{mg} / \mathrm{kg}$, $0.80 \mathrm{mg} / \mathrm{kg}$ 으로 대조구와의 통계적 유의차가 존재하지 않 았으며 그 농도 또한 현저히 낮은 것으로 조사되었다. 이외 의 중금속 농도는 1 지역 기준치 이하로 조사되었다.

$\mathrm{Al}$ 의 경우 레드머드에 다량 함유되어 있고, 토양에 처리 
시 그 함량은 유의하게 증가하였다. $\mathrm{Al}$ 은 토양환경보전법 에서 지정하는 토양오염 기준 항목은 아니지만 $\mathrm{Al}$ 은 토양 에 유입 되었을 때 식물독성을 유발할 수 있다. 독성을 유 발하는 주요한 형태는 활성 $\mathrm{Al}^{3+}$ 이며 이 상태는 작물에 대 한 $\mathrm{Al}$ 스트레스 지표로 이용된다. ${ }^{31}$ 일반적으로 토양 $\mathrm{pH}$ 와 활성 $\mathrm{Al}^{3+}$ 이온은 음(-)의 상관관계가 있으며 산성화된 토양 은 활성 $\mathrm{Al}^{3+}$ 이온이 증가하여 $\mathrm{Ca}, \mathrm{Mg}, \mathrm{P}$ 등의 영양물질 흡 수를 저해한다. ${ }^{32)}$ 반대로 중화되어 $\mathrm{pH}$ 가 7 8 사이인 토양 에서는 $\mathrm{Al}^{3+}$ 과 hydroxyl group $(-\mathrm{OH})$ 이 $\mathrm{Al}(\mathrm{OH})_{3}$ 의 형태로 침전 된다. 따라서 산성화된 토양은 적절한 중화 과정을 필 요로 하며 본 연구에서 개량제를 처리한 토양은 중성에 가 까운 $\mathrm{pH}$ 로 나타나 $\mathrm{Al}$ 에 대한 식물 독성작용은 미미할 것 으로 판단된다.

상추 수확 후 식물체 내의 중금속을 분석한 결과는 Table 7과 같다. 식품의약품안전처에서 고시하는 중금속 잔 류 기준의 대상식품은 농산물, 축산물, 수산물 및 가공식품 등이 존재한다. 그 중 농산물의 중금속 잔류 기준 항목은 $\mathrm{Pb}$ 과 $\mathrm{Cd}$ 만을 대상으로 하며 곡류, 특히 쌀의 경우에만 $\mathrm{As}$ 항목이 추가 적용 되어있다. 본 연구에서 재배된 엽채류인 상추의 경우 중금속 잔류 농도 기준은 $\mathrm{Pb}$ 이 $0.3 \mathrm{mg} / \mathrm{kg}$ 이 하, $\mathrm{Cd}$ 은 $0.2 \mathrm{mg} / \mathrm{kg}$ 이하로 명시되어 있으며 분석된 농도와 비교 시 $\mathrm{Pb}$ 은 불검출(N.D.), $\mathrm{Cd}$ 은 $0.10 \sim 0.14 \mathrm{mg} / \mathrm{kg}$ 이 검출 되어 기준치 미달로 조사되었다. 따라서 $1 \%$ 의 레드머드와 $2 \%$ 의 바이오차 처리 시에도 중금속 잔류 농도 기준을 만 족하는 것으로 나타났다.

\section{4. 결론}

본 연구는 산업 폐기물인 레드머드와 농업 부산물인 왕 겨로 제조된 바이오차를 활용하여 산성화된 토양을 중화하 고 작물을 생육하여 토양개량 효과를 조사하였다.

1) 산성토양 $(\mathrm{pH} 4.84)$ 에 레드머드를 첨가하였을 때(T1), $\mathrm{pH}$ 는 6.99로 유의하게 상승하였고, 레드머드와 바이 오차를 첨가하였을 때(T2), $\mathrm{pH}$ 는 7.14로 평균값은 증 가하였지만 $\mathrm{T} 1$ 과 $\mathrm{T} 2$ 간의 통계적인 유의차는 없었다.

2) 염류농도(EC) 조사결과 $\mathrm{T} 1$ 과 $\mathrm{T} 2$ 에서 염류농도 값은 적정 기준 $(2.0 \mathrm{dS} / \mathrm{m})$ 이하로 조사되어 작물에 염해 피 해는 없을 것으로 판단된다. 특히 레드머드는 $\mathrm{Na}^{+}$함 량이 높은 것으로 조사되었고 $\mathrm{Na}^{+}$이온은 염류농도 (EC)와 정 $(+)$ 의 상관관계가 있는 것으로 분석되어 레 드머드 시용에는 염류농도 상승에 주의를 필요로 할 것으로 판단된다.

3) 토양 비옥도의 지표인 $\mathrm{CEC}$ 는 대조구에서 $7.56 \mathrm{cmol}_{d} \mathrm{~kg}$, $\mathrm{T} 1$ 과 $\mathrm{T} 2$ 에서 각각 $9.21 \mathrm{cmol}_{\mathcal{d}} \mathrm{kg}, 9.80 \mathrm{cmol}_{\mathcal{J}} \mathrm{kg}$ 으로 상승 하여 레드머드와 바이오차를 첨가한 $\mathrm{T} 2$ 에서 가장 높은 값을 나타냈다.
4) 처리구 시료(T1, T2)를 이용하여 상추 생육실험을 진 행한 결과 대조구에 비해 처리구에서 엽장(length), 엽 폭(width), 생체중(weight), 건체중(dry weight)의 생육 지표가 우위에 있는 것으로 조사되었고, 특히 $\mathrm{T} 1$ 보다 $\mathrm{T} 2$ 에서 생육지표가 더 높게 조사되었다.

5) 중금속 농도 분석결과 레드머드에서 $\mathrm{Cd}$ 이 토양오염 1 지역 우려기준을 초과하였지만 레드머드와 바이오차 를 첨가한 처리구(T1, T2)에서는 토양오염 1지역 우려 기준 미만으로 조사되었다. 상추 수확 후 상추 내의 중금속 농도를 분석한 결과 엽채류 기준 항목인 $\mathrm{Pb}$ 과 $\mathrm{Cd}$ (식품의약품안전처 고시 기준) 모두 기준치 이하로 조사되었다.

산업 폐기물인 레드머드와 농업 부산물을 이용하여 제조 된 바이오차를 적용하여 토질과 작물의 생육환경을 보다 긍정적인 방향으로 개선하였다. 레드머드만을 이용한 기존 의 연구에서 바이오차를 추가 적용함으로써 한층 향상된 토질 개선효과를 확인하였다. 더불어 폐기물을 토양과 작 물에서 오염되지 않는 범위 내에서 활용가능하다는 것을 입증하였다. 따라서 레드머드와 바이오차를 개량제로 활용 하여 토양을 개량함으로써 폐기물 자원순환 측면에 기여할 수 있을 것으로 기대된다.

\section{References}

1. Ministry of trade, industry and energy, A case study on waste recycling from developed countries(2017).

2. J. E. Lim, D. H. Moon, K. R. Kim, J. E. Yang, S. S. Lee, Y. S. Ok, Heavy metal stabilization in soils using waste resources - A critical review, J. Appl Biol. Chem., 58(2), 157-174(2015).

3. Y. H. Park, Y. N. Jung, Overview of bauxite residues and processing status of domestic and overseas, Magazine of RCR, 12(4), 22-27(2017).

4. H. S. Hong, Y. L. Kim, H. J. Cho, D. W. Kim, D. W. Kim, H. J. Kim, Y. Kim, S. P. Kim, Overview and future concerns for red mud recycling technology and industry, J. of Korean Inst. of Resources Recycling, 26(5), 12-21(2017).

5. J. Kim, S. J. Park, D. Shin, D. H. Moon, Y. G. Kim, B. C. Ryu, J. H. Park, Effect of ameliorant with bauxite byproduct on the germination and growth of lettuce by acidic soil neutralization, J. Korean Soc. Environ. Eng., 40(6), 258-266 (2018).

6. Y. H. Park, Y. N. Jung, Environmental stability of bauxite residues for recyling in the construction industry, Magazine of RCR, 12(4), 28-33(2017).

7. Ministry agriculture, food and rural affairs, Development strategy of biomass energy production, Publication registration number 11-1543000-000685-01(2014).

8. C. G. Lee, S. Y. Lee, S. Y. Joo, L. H. Cho, S. Y. Park, S. H. Lee, K. C. Oh, D. H. Kim, A study on agricultural 
by-products for biomass-to-energy conversion and korean collecting model, New \& Renewable Energy, 13(1), 27-35 (2017).

9. K. H. Han, Y. S. Zhang, K. H. Jung, H. R. Cho, Y. K. Sonn, Evaluating germination of lettuce and soluble organic carbon leachability in upland sandy loam soil applied with rice husk and food waste biochar, Journal of agricultural science, 41(4), 369-377(2014).

10. J. D. Shin, Y. S. Choi, E. J. Choi, M. S. Kim, J. W. Heo, Evaluation of efficiency to plant growth in horticultural soil applied biochar pellet for soil carbon sequestration, Journal of the Korea Organic Resources Recycling Association, 25(3), 73-78(2017).

11. T. K. Oh, J. H. Lee, S. H. Kim, H. C. Lee, Effect of biochar application on growth of chinese cabbage (Brassica chinensis), Korean Journal of Agricultural Science, 44(3), 359-365(2017).

12. X. Tan, Y. Liu, G. Zeng, X. Wang, X. Hu, Y. Gu, Z. Yang, Application of biochar for the removal of pollutants from aqueous solutions, Chemosphere, 125, 70-85(2015).

13. T. M. Abdel-Fattah, M. E. Mahmoud, S. B. Ahmed, M. D. Huff, J. W. Lee, S. Kumar, Biochar from woody biomass for removing metal contaminants and carbon sequestration, Journal of Industrial and Engineering Chemistry, 22, 103-109(2015).

14. J. L. Smith, H. P. Collins, V. L. Bailey, The effect of young biochar on soil respiration, Soil Biology \& Biochemistry, 42(12), 2345-2347(2010).

15. S. J. Park, M. Rana, D. Shin, J. H. Park, Lignin decomposition in hydrothermal liquefaction process using red-mud catalyst, J. Korean Soc. Environ. Eng., 41(3), 132-139(2019).

16. K. H. Lim, B. H. Shon, Study on recovery of heavy metals from red mud by using the ultrasonic waves, Journal of the Korea Academia-Industrial cooperation Society, (16)1, 906-913(2015).

17. J. S. Kim, S. W. Han, I. G. Hwang, J. H. Bae, W. Z. Choi, Synthesis of pellet-type red mud adsorbents for removal of heavy metal ions, Journal of the Korean Institute of Resources Recycling, 9(1), 44-51(2000).

18. Q. Abbas, G. Liu, B. Yousaf, M. U. Ali, H. Ullah, M. A. M. Munir, R. Liu, Contrasting effects of operating conditions and biomass particle size on bulk characteristics and surface chemistry of rice husk derived-biochars, Journal of Analytical and Applied Pyrolysis, 134, 281-292(2018).

19. S. Abrishamkesh, M. Gorji, H. Asadi, G. H. Bagheri-
Marandi, A. A. Pourbabaee, Effects of rice husk biochar application on the properties of alkaline soil and lentil growth, Plant Soil Environ., 61(11), 475-482(2015).

20. J. E. Lim, S. S. Lee, Y. S. Ok, Efficiency of poultry manure biochar for stabilization of metals in contaminated soil, J. Appl Biol. Chem., 58(1), 39-50(2015).

21. L. B. Cimdina, N. Borodajenko, Research of calcium phosphates using fourier transform infrared spectroscopy, Infrared spectroscopy-materials science, engineering and technology, T. Theophile(Ed.), Intech, pp. 123-148(2012).

22. M. Ahmad, A. U. Rajapaksha, J. E. Lim, M. Zhang, N. Bolan, Biochar as a sorbent for contaminant management in soil and water : A review, Chemosphere, 99, 19-33(2014).

23. J. U. Kim, D. Y. Hyun, Y. C. Kim, J. W. Lee, I. H. Jo, D. H. Kim, K. H. Kim, J. K. Sohn, Effects of salt in soil condition on chlorophyll fluorescence and physiological disorder in panax ginseng C. A. meyer, J. Medicinal Crop Sci., 23(6), 446-453(2015).

24. S. D. Hong, B. G. Kang, J. J. Kim, Optimum fertilization based on soil testing for chinese cabbage cultivation in plastic film houses, Journal of Soil Science and Fertilizer, 31(1), 16-24(1998).

25. H. D. Chung, I. S. Jang, Y. J. Choí, Effects of soil EC on seed germination, seedling growth, initiation of female flower and fruit growth of cucumber plants, Journal of horticultural science \& technology, 19(4), 495-500(2001).

26. I. S. Ryu, I. H. Lee, S. W. Hwang, The chemical properties of plastic-house soil and yield responses of green pepper, Journal of Soil Science and Fertilizer, 28(3), 241-248(1995).

27. Rural development administration, Soil management of organic farmland(2017).

28. D. J. Kim, B. K. Ahn, J. H. Lee, Impact of environmentallyfriendly organic agro-materials on chemical properties of remediated soils, Journal of organic agriculture, 21(4), 753-767(2013).

29. S. H. Woo, Biochar for soil carbon sequestration, Clean technology, 19(3), 201-211(2013).

30. W. G. Jeong, Understanding soil acidity and management of acid soil, Korean Society Of Soil Sciences and Fertilizer, (25), 29-35(2006).

31. I. B. Lee, J. S. Lim, K. W. Chang, Effect of water treatment sludge on growth of rice seedling, Journal of environmental agriculture, 25(4), 382-385(2006).

32. Korea forest service, Evaluation of forest soil characteristics, Publication registration number 11-1400377-001080-01(2018). 